A number of points emerged as to the present state of knowledge of unimolecular reactions. In the first place, there now seems to be a large number of well-established gas-phase unimolecular reactions. Secondly, experimental investigations of the lowpressure region have enabled relative collision efficiencies for energy transfer to be estimated. Thirdly, there appears to be quite a wide range of frequency factors. Fourthly, it is desirable to extend the theoretical treatment along quantal lines. Finally, recognition of the possible multiplicity of reaction paths may be a fruitful line of approach.

The meeting closed with an expression of gratitude to Prof. C. K. Ingold, of University College, London, through whose interest the conference was made possible.

${ }^{2}$ Slater, N. B., Proc. Roy. Soc., A, 194, 112 (1948).

${ }^{2}$ Slater, N. B., Phil. Trans., A, 246, 57 (1953); Proc. Roy. Soc., A, 218, 224 (1953).

${ }^{3}$ Pritchard, H. O., Sowden, R. G., and Trotman-Dickenson, A. F., Proc. Roy, Soc, A, 217, 563 (1953); 218, 416 (1953).

${ }^{4}$ Howlett, K. E., J. Chem. Soc., 3695, 4487 (1952).

${ }^{5}$ Howlett, K. E., J. Soc. Chem. Indust., 1175 (1952).

- For all references see Peard, M. G., Stubbs, F. J., and Hinshelwood, C. N., Proc. Roy. Soc., A, 214, 471 (1952).

"Chilton, H. T. J., and Gowenlock, B. G., J. Chem. Soc., 3232 (1953)

${ }^{8}$ Gowenlock, B. G., Polanyi, J. C., and Warhurst, E., Proc. Roy. Soc., A, 218, 269 (1953).

' Chilton, H. T. J., and Gowenlock, B. G. (to be published). ${ }^{10}$ Chilton, H. T. J., and Gowenlock, B. G., Trans. Farad. Soc., 49,

${ }^{11}$ Green, J. H. S., Harden, G. D., Maccoll, A., and Thomas, P. J. J. Chem. Phys., 21, 178 (1953).

\section{SCIENTIFIC AND TECHNICAL DOCUMENTATION IN TURKEY}

$\mathrm{T}$

ECHNICAL Assistance projects in Turkey, some of them operating, others to come into operation if and when funds are available, cover a great variety of subjects: public administration, economic research, civil aviation, statistics, maternal and child health, diseases control, water resources development, oil resources development, fisheries development, hydrogeology, seismology, and various others. Bibliographical and documentation services, needed by many of them, are also included.

The National Bibliographical Centre is one of three Unesco projects under the Expanded Programme of Technical Assistance in Turkey. It was set up in 1952, with the assistance of two library experts : a specialist in bibliography, from France, and $a_{0}$ specialist in documentation, from the United Kingdom. The Centre is housed at the National Library in Ankara and, apart from co-operating with Technical Assistance projects, maintains close contact with government departments, university faculties, scientific societies, educational institutes, research stations, industrial undertakings and, of course, other libraries.

The main objective of the Bibliographical Centre is to assure the availability of information to all Turkish programmes for scientific, technical and economic development. This emphasis on Turkish affajrs does not, however, preclude it from collaborating in a system of international exchanges of scientific information and so render valuable service to the region, and to the world.

With financial aid earmarked for the purpose by Unesco Technical Assistance, the Centre brought together a much-needed collection of handbooks, monographs, bibliographies, catalogues and other library tools in many different languages. This useful reference library, open to bona fide research workers, has meanwhile become indispensable to staff and readers alike.

Under its regular programme, Unesco has estab. lished in Istanbul a branch office of its Middle Fast Science Co-operation Office, the headquarters of which are located in Cairo. The Istanbul Office acts as an outpost of Unesco in Turkey, and among its activities has been the ad hoc supply of scientific information requested by Turkish scientific workers. The United States Information Service offers similar facilities within the range of United States sources. The Middle East Science Co-operation Office in Cairo issues an abstracting journal in the English language which covers the Middle East countries and includes several periodicals published in Turkey.

Fuller coverage of Turkish periodicals in the pure and applied sciences, technology and so on, is now provided by "Türkiye Makaleler Bibliyografyası" ("Bibliographie des articles parus dans les périodiques turcs'), issued by the National Bibliographical Centre. It is published at irregular intervals, is arranged by Universal Decimal Classification numbers, with the titles of articles in Turkish and French, and has an author index. Translations or abstracts of specified papers, and microfilms of the original texts, are supplied on request.

As a means of meeting and co-ordinating incoming demands for foreign articles which may be available in Turkey, the Bibliographical Centre has compiled, and keeps currently up to date, a union catalogue of foreign periodicals in Turkish libraries. It is now in its second edition.

Scientific papers published in other journals are obtained as microfilms from abroad, against payment in Unesco coupons or, mostly, on an exchange basis. The first exchange arrangement was concluded in March 1953, between the National Bibliographical Centre in Ankara and the Centre National de la Recherche Scientifique in Paris. This places at the disposal of Turkish men of science a substantial part of the world's scientific literature, and makes Turkish contributions available to scientists in the West. The microfilm laboratory at the Turkish National Library, previously almost exclusively engaged on the copying of manuscripts, has adjusted itself admirably to the rew tasks, and a microfilm camera and microfilm reading machines have been imported from Britain.

Approach to documentation may be two-fold-short-term and long-term-one taking care of immediate needs and the other making provision for potential requirements. It has been the policy of the Centre to prepare for both, trying to do justice at the same time to border-line cases, of which there a.re many.

Inquiries for documentation were received from quarters interested in subjects as widely apart as : palæontological research; fish culture and fish industry ; methods of preserving and utilizing agricultural products; and industrial accidents and workmen's compensation-to mention only a few. It had, moreover, been agreed between Unesco and the World Health Organization, also represented in Turkey, that every possible help should be given to medical libraries and medical documentation in Turkey. The Bibliographical Centre was also called upon to act as liaison for a direct approach between research and study projects in Turkey and their opposite numbers elsewhere. An agricultural research 
station was referred to the Food and Agriculture Organization; an industrial information unit put in touch with the Department of Scientific and Industrial Research; a chemistry department with the Gmelin Institut für Anorganische Chemie; and a government agency with the International Organization for Standardization. Such liaison has been essential, for, through it, has been created a broader footing for scientific and technical documentation; in the terms of Technical Assistance, "the activity started on the right lines". LuCIA MOHOLY

\section{LATERITES AND BAUXITES OF ANTRIM}

T

HE first memoir to be published by the Geological Survey of Northern Ireland*, prepared by Mr. Y. A. Eyles and other workers, will be widely recognized as a contribution to the geochemistry and mineralogy of laterite and bauxite of outstanding importance and permanent value. Equally welcome will be the promised companion volume on the detailed geology of these rocks as they occur in the Interbasaltic Horizon of Co. Antrim. The present work deals with the nature of the chemical changes concerned in the process of lateritization and of the composition of the Interbasaltic lateritic rocks themselves. The latter were formed during a prolonged pause in the Tertiary volcanic activity responsible for the Antrim basalts. At an early stage in this Interbasaltic period there was a brief recrudescence of activity characterized by the eruption of highly silicic lavas. Intense erosion followed, with removal of most of the rhyolites and complementary deposition of thin sediments largely composed of rhyolitic debris. Towards the end of the lateritization period a thin coal seam was formed from the vegetation that flourished over the area. An interesting note records that Dr. J. B. Simpson finds the floral remains from a coal associated with bauxite near Portrush to be of essentially the same age as the corresponding horizon in Mull, to which he is inclined to ascribe a late Miocene or early Pliocene age. This is so much later than has hitherto been thought probable that the publication of Dr. Simpson's palæobotanical researches will be eagerly awaited. The Interbasaltic period was terminated by the outpouring of the Giant's Causeway and later basaltic flows. At the same time, or later, basaltic dykes were intruded, and these, cutting through the lateritic rocks, effected marked metamorphic changes.

The Irish laterites and bauxites were formed in two distinct stages : $(a)$ alteration to lithomarge, consisting of kaolinite or halloysite ; and $(b)$ lateritization, involving further desilication with formation of gibbsite $\left(\mathrm{Al}_{2} \mathrm{O}_{3} \cdot 3 \mathrm{H}_{2} \mathrm{O}\right)$ together with oxides of iron and titanium. With long-continued operation of the process the iron oxides tend to concentrate towards the surface, forming an increasingly ferruginous laterite and eventually a workable iron ore, overlying a layer of richly aluminous laterite or bauxite. In Ireland, unfortunately, neither complete desilication of lithomarge nor clean separation of aluminous from ferruginous laterite has occurred over more than

* The Composition and Origin of the Antrim Laterites and Bauxites. By V. A. Eyles, with mineral determinations by $X$-ray methods by F. A. Bannister (British Museum, Natural History) and G. W. Brindley and $\mathbf{J}$. Goodyear (University of Leeds). (Memoir of the Geological Survey of Northern Treland.) Pp. vi +90 . (Belfast: H.M. Stationery limited areas. The prevailing types are lateritic lithomarges and ferruginous or siliceous laterites. It appears that quartz, originally present in a parental roek, may persist unchanged; the possibility of, and the conditions governing, the total elimination of quartz still require further investigation. A chemical method, devised and described by Mr. C. O. Harvey, is given for the quantitative determination of quartz in the presence of combined silica.

Much valuable information has been obtained from the application of the X-ray diffraction technique to selected specimens. The chief minerals recognized include meta-halloysite and kaolinite; gibbsite and boehmite (but not dirspore); hæmatite, goethite and magnetite; and anatase. Chamosite has been found in certain parts of the laterite horizon which exhibit a greenish tinge. Since the formation of chamosite requires reducing conditions, its occurrence implies that it is a secondary mineral relative to the lateritic minerals with which it is now associated. The abundance and distribution of various minor elements has been determined by Dr. S. Landergren, whose results demonstrate enrichment of the laterites in vanadium and probably in chromium.

Discussing the geological conditions influencing the formation of the several hydrated oxides of aluminium, Mr. Eyles points out that the widespread distribution and prevalence of the gibbsite type of bauxite suggests that this is the variety normally developed. He presents detailed evidence to justify the tentative conclusions: "(i) that the formation of monohydrates in large amounts results from a change of geological environment superimposed on gibbsitic laterites after the formation of the latter; (ii) that increased pressure resulting from subsidence, or dynamic action, or both, and not rise in temperature alone, may often be the main, though possibly not the sole, factor causing the large-scale development of monohydrates of alumina; (iii) that while igneous intrusions or lava flows alone may cause localized development of boehmite in laterite deposits, pressure is probably essential for the formation of diaspore in large quantities".

Mr. Eyles and his colleagues have made this a model investigation of its kind. It is to be hoped that their lead will be followed, so that it may no longer be necessary to direct attention to the fact that "descriptions of foreign laterite are not always sufficiently complete to permit generalizations to be drawn from the facts presented". A. Holmes

\section{CARNEGIE TRUST FOR THE UNIVERSITIES OF SCOTLAND}

\section{ANNUAL REPORT FOR 1952-53}

THE fifty-second annual report of the Carnegie Trust for the Universities of Scotland, covering the academic year 1952-53*, deals with a period before the most recent regulations of the Scottish Education Department for the award of bursaries by Scottish education authorities became effective so far as the Trust is concerned; but the executive committee to the trustees points out that the amounts awarded in terms of these regulations constitute a

* The Carnegie Trust for the Universities of Scotland. Fifty-second Annual Report (for the Year 1952-53). Submitted by the Executive (Edinburgh : $T$ and 